\title{
Shade Trees Spatial Distribution and Its Effect on Grains and Beverage Quality of Shaded Coffee Trees
}

\author{
Francisco José da Silva Neto ${ }^{(D)},{ }^{1}$ Kátia Priscilla Gomes Morinigo, \\ Nathalia de França Guimarães (iD), ${ }^{2}$ Anderson de Souza Gallo (iD, ${ }^{2}$ \\ Maicon Douglas Bispo de Souza, ${ }^{1}$ Rubismar Stolf, ${ }^{1}$ and Anastácia Fontanetti $\mathbb{D}^{1}$ \\ ${ }^{1}$ Department of Rural Development, Universidade Federal de São Carlos (UFSCar), Rodovia Anhanguera, \\ Km 174, Araras, SP, Brazil \\ ${ }^{2}$ Department of Soil, Institute of Agronomy, Universidade Federal Rural do Rio de Janeiro (UFRRJ), \\ BR-465, Km 7, Seropédica, RJ, Brazil
}

Correspondence should be addressed to Francisco José da Silva Neto; franciscojose331@gmail.com and Anastácia Fontanetti; anastacia@ufscar.br

Received 30 September 2017; Accepted 27 December 2017; Published 25 February 2018

Academic Editor: Fernando M. Botelho

Copyright (C) 2018 Francisco José da Silva Neto et al. This is an open access article distributed under the Creative Commons Attribution License, which permits unrestricted use, distribution, and reproduction in any medium, provided the original work is properly cited.

\begin{abstract}
Shading coffee trees has gained importance, especially among smallholders, as an option to improve the products' quality, therefore acquiring place at the specialty coffee market, where consumers are willing to give bonus for quality. This work aims to evaluate the influence of shade trees' spatial distribution among coffee trees' agronomic characteristics, yield, and beans and cup quality of shaded coffee trees. The experimental design consisted of completely randomized blocks with six repetitions and four treatments: coffee trees on shade trees planting rows, distant one meter from the trunk; coffee trees on shade trees planting row, distant six meters from the trunk; and coffee plants between the rows of shade trees, parallel to the previous treatments. The parameters analyzed were plant height, canopy diameter, plagiotropic branches' length, yield, coffee fruits' phenological stage, ripe cherries' Brix degree, percentage of black, unripe, and insect damaged beans, bean size, and beverage quality. Shade trees quickened coffee fruits' phenological stage of coffee trees nearest to them. This point also showed the best beverage quality, except for overripe fruits. The remaining parameters evaluated were not affected by shade trees' spatial distribution.
\end{abstract}

\section{Introduction}

Brazilian production processes of specialty coffee have grown in the past decades due to the increase of demand from international markets [1]. The concept of specialty coffee is broad and involves characteristics such as superior beverage quality, rare varieties, and location of cultivation but also can be related to ecological, economic, or social sustainability [2]. Still, coffee quality is the result of complex interactions between the environment, management, and plant genetics [3].

The implantation of shade trees in coffee plantation can bring about many benefits to the agroecosystem, such as temperature reduction of air, soil, and leaf surface [4], as well as the thermal amplitude [5], and softening the effect of biennial bearing [6]. It also protects coffee plants from strong winds, rains, or hail [7] and increases nutrient cycling and soil organic matter [8]. This can significantly increase crop production stability.

Shade trees also impact quality because maturation is more uniform under shade [9]. Coffee beans' size is enlarged as a consequence of fewer flowers and, also, the existence of less fruits per plant once coffee trees are shaded [6]. This benefic effect is possible in sites under optimal [10] and suboptimal [11] conditions for coffee plants. However, Bosselmann et al. [12] found a decrease in coffee quality when shade trees were present in plantations at high altitudes.

However, conditions in shaded coffee plantations are not spatially stable, especially in systems with lower rates of soil 


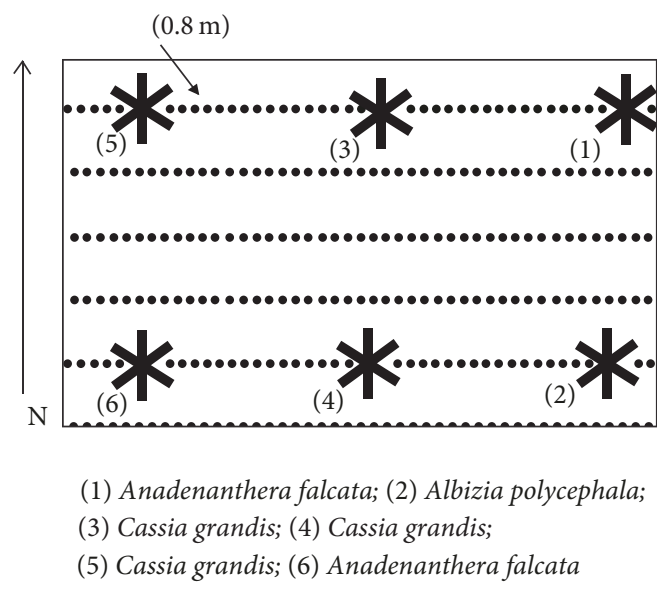

(a)

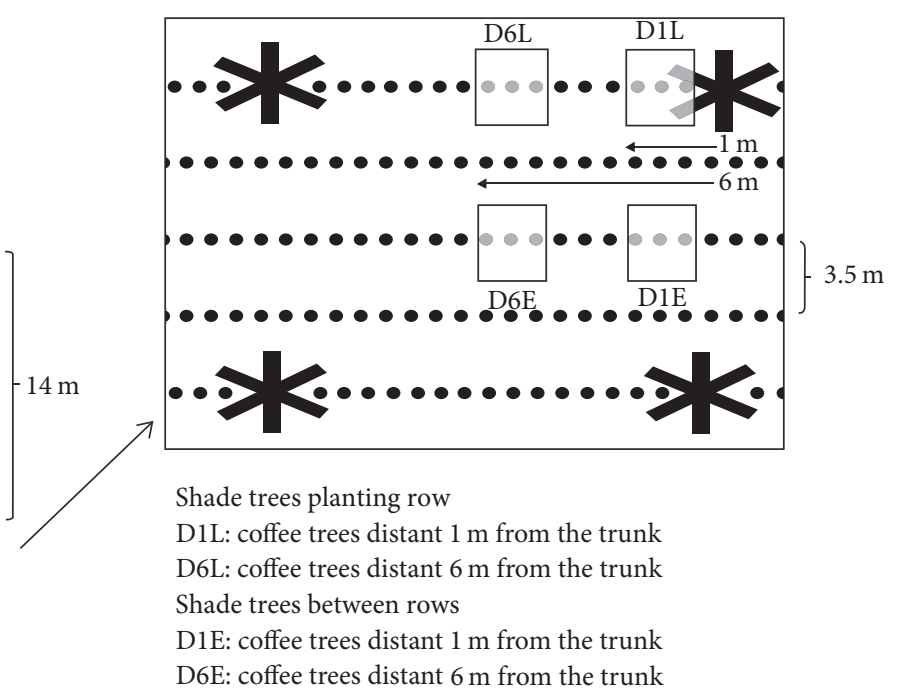

(b)

FIGURE 1: Graphical representation of the shaded coffee plantation (a); detailing of the treatments (b). Santo Antônio do Jardim, SP, 2015.

TABLE 1: Climate data observed during the months in which the experiment was conducted. Santo Antônio do Jardim, SP, 2015.

\begin{tabular}{|c|c|c|c|c|c|c|c|c|c|}
\hline \multirow{2}{*}{ Months } & \multirow{2}{*}{$\begin{array}{c}\mathrm{RD} \\
\text { Total }\end{array}$} & \multicolumn{2}{|c|}{ PREC $(\mathrm{mm})$} & \multicolumn{3}{|c|}{$T\left({ }^{\circ} \mathrm{C}\right)$} & \multicolumn{3}{|c|}{$\mathrm{RH}(\%)$} \\
\hline & & Total & Average & Min & Max & Average & Min & Max & Average \\
\hline $\mathrm{Feb}$ & 14 & 348 & 12.4 & 19.9 & 28.3 & 24.1 & 80 & 94 & 87 \\
\hline Mar & 18 & 475 & 15.3 & 18.1 & 26.6 & 22.3 & 87 & 98 & 92 \\
\hline Apr & 4 & 165 & 5.5 & 17.5 & 27.2 & 22.3 & 70 & 93 & 81 \\
\hline May & 7 & 123 & 4.0 & 14.6 & 23.1 & 18.8 & 88 & 98 & 93 \\
\hline Jun & 3 & 27 & 0.9 & 14.7 & 24.4 & 19.5 & 89 & 95 & 92 \\
\hline Jul & 2 & 30 & 1.0 & 14.5 & 24.4 & 19.4 & 90 & 95 & 92 \\
\hline Aug & 1 & 10 & 0.3 & 15.0 & 25.7 & 20.3 & 78 & 92 & 85 \\
\hline
\end{tabular}

RD: rain days; PREC: precipitation; $T$ : temperature; RH: relative air humidity. Source: meteorological station of the Retiro Santo Antônio farm (2015).

cover by trees. In the farthest points from the shade trees, microclimate conditions are rather similar to the ones in fullsun systems [13].

Therefore, this work aims to evaluate the influence of shade trees' spatial distribution on growth and productivity of coffee trees as well as on coffee quality.

\section{Materials and Methods}

2.1. Research Site. The research took place between April and August 2015 at Retiro Santo Antônio farm, located in Santo Antônio do Jardim, São Paulo state, Brazil ( $22^{\circ} 06^{\prime} \mathrm{S}$ and $46^{\circ} 40^{\prime} \mathrm{W}, 850 \mathrm{~m}$ above sea level). The climatic conditions were categorized by Köppen [14] as Cwb, temperate with dry winters and warm summers. Maximum and minimum temperature and air relative humidity are shown in Table 1, as well as rainfall volumes. Soil was classified as Red-Yellow Argisol [15]. Soil chemical characteristics are described in Table 2.

A site implanted in 2007 with the coffee variety of Obatã Vermelho and the arrangement of $0.8 \times 3.5$ meters $(3,570$ plants $\mathrm{ha}^{-1}$ ) was used. Shade trees were implanted in 2009.
The species used were Anadenanthera falcata, Albizia polycephala, and Cassia grandis with the arrangement of $15.0 \times$ 14.0 meters (44 plants ha ${ }^{-1}$ ) (Figure 1 ).

Fertilization was carried out according to soil chemical characteristics and Raij et al. [16] recommendation. Protected urea was applied three times a year, in the dosage of $50 \mathrm{~g}$ per plant, the last applications being done in November and December 2014 and February 2015; potassium chloride was applied twice a year, $10 \mathrm{~g}$ per plant, the last one being realized in February 2015; chicken litter and straw of coffee were applied once a year in the dosage of $1 \mathrm{~kg}$ per plant, the last applied in October 2014. No fertilization with phosphorus or boron was used during the experiment.

2.2. Treatments and Experimental Design. The experiment design was of completely randomized blocks with six repetitions and four treatments, spatially distributed due to shade trees' localization: coffee trees on shade trees planting rows, distant one meter from the trunk (D1L); coffee trees on shade trees planting rows, distant six meters from the trunk (D6L); coffee plants between the rows of shade trees, parallel to 
TABLE 2: Soil chemical characterization in depths of $0,0-0,20 \mathrm{~m}$ and $0,20-0,40 \mathrm{~cm}$ of shaded coffee plantations. Santo Antônio do Jardim, SP, 2015.

\begin{tabular}{lccc}
\hline Depth & Unit & $0,0-0,20 \mathrm{~m}$ & $0,20-0,40 \mathrm{~m}$ \\
\hline $\mathrm{pH}$ & $\mathrm{CaCl}_{2}$ & 5.12 & 3.20 \\
$\mathrm{P}$ & $\mathrm{Mg} \cdot \mathrm{dm}^{3}$ & 36.13 & 30.00 \\
$\mathrm{M} \cdot \mathrm{O}$ & $\mathrm{g} \cdot \mathrm{dm}^{3}$ & 23.96 & 21.92 \\
$\mathrm{~K}$ & $\mathrm{mmol} \cdot \mathrm{dm}^{-3}$ & 2.96 & 3.06 \\
$\mathrm{Ca}$ & $\mathrm{mmol}_{\mathrm{c}} \cdot \mathrm{dm}^{-3}$ & 29.80 & 24.94 \\
$\mathrm{Mg}$ & $\mathrm{mmol}_{\mathrm{c}} \cdot \mathrm{dm}^{-3}$ & 13.16 & 11.28 \\
$\mathrm{H}+\mathrm{Al}$ & $\mathrm{mmol}_{\mathrm{c}} \cdot \mathrm{dm}^{-3}$ & 27.54 & 34.63 \\
$\mathrm{Al}$ & $\mathrm{mmol}_{\mathrm{c}} \cdot \mathrm{dm}^{-3}$ & 1.54 & 2.48 \\
$\mathrm{SB}$ & $\mathrm{mmol}_{\mathrm{c}} \cdot \mathrm{dm}^{-3}$ & 45.94 & 39.29 \\
$\mathrm{CEC}$ & $\mathrm{mmol}_{\mathrm{c}} \cdot \mathrm{dm}^{-3}$ & 73.48 & 73.89 \\
$\mathrm{~V}$ & $\% \%^{\circ}$ & 63.60 & 54.88 \\
\hline
\end{tabular}

SB: sum of bases; CEC: cation-exchange capacity; V: base saturation.

treatments D1L and D6L (D1E and D6E) (Figure 1). The plot consisted of three consecutive coffee trees.

\subsection{Evaluations}

2.3.1. Phenological Evolution. To determine the ideal time to harvest, the phenological evolution of coffee cherries was tracked once the endosperm expansion has finished. Pezzopane et al.'s [17] methodology was adapted to contemplate only cherry phenological evolution, (1) green, (2) yellowish green, (3) cherry, and (4) overripe. Four productive branches, two in each exposition side to the sun, were marked with a plastic ribbon so the same cherries were always evaluated. The evaluations took place on April 24th, May 1st and 14th, and July 28 th.

2.3.2. Coffee Trees' Agronomical Characteristics and Brix Degree. Coffee trees' agronomical characteristics were evaluated previous to harvesting. Plant height, given in meters, was measured from the insertion of the orthotropic branch in the ground to the apical bud. Canopy diameter, in meters, was measured perpendicular to planting rows, measuring the farthest distance between the first pair of leaves from opposites plagiotropic branches. Finally, plagiotropic branch length per plant, given in centimeters, was the mean of ten random branches.

Brix degree evaluation used the juice of three ripe cherries per plot. Cherries were squished in the optical reader of a portable refractometer. The results were given in ${ }^{\circ} \mathrm{Bx}$; each degree corresponds to one gram of sucrose in 100 grams of solution.

2.3.3. Coffee Yield. Harvest was conducted manually by strippicking between July 28 and 30, when more than half of the cherries in the hole experiment were ripe. Cherries were washed, to remove impurities, and separated into unripe fruits (UF), ripe fruits (RF), and overripe fruits (OF). Each group of cherries was weighed, in a semianalytic balance machine, separately and together, so the total weight was revealed. Cherries volume was measured with a $2,000 \mathrm{ml}$ graduated cylinder.
Posteriorly, cherries were allocated separately in plastic net bags and naturally dried in the sun over a slab of concrete until 13\% of humidity was reached. Then, coffee beans were mechanically peeled (Carmomaq, Tecnologia e Inovação para a Indústria do Café, model: DRC 1, number: 9498, year: 2012); in this operation, the parchment was also removed and once more weighed. Immediately after, beans' humidity was determined with a benchtop grain moisture tester (Moisture and Purity Tester G650, Gehaka Agri).

2.3.4. Coffee Quality. Samples of $300 \mathrm{~g}$ of green coffee beans of each plot and each cherry stage (unripe, ripe, and overripe) were analyzed by the Qualicafex Specialty Coffees company. There, the percentage of defect (black, unripe, and insect damaged beans), sieve retention, and cup quality were assessed. Cup quality test follows the SCCA (Specialty Coffee Association of America) guidelines and the notes are given according to Brazilian law (Brazil, 2003). In Brazil, Arabic coffee quality is divided into seven subgroups. In order from the best for wort quality, the subgroups are (i) strictly soft: coffee that has beverage with all the characteristics of aroma and taste of the soft beverage, but strongly accentuated; (ii) soft: coffee beverage with smooth, sweet, and pleasant taste and aroma; (iii) softish: coffee beverage with weakly sweet and smooth, but still with no signs of astringency; (iv) hard: coffee beverage with acrid and astringency taste, but still with no signs of odd flavors; (v) Rioysh: coffee beverage with soft flavor, slightly resembling iodoform; vi) Rio: coffee beverage with typical flavor of iodoform; (vii) Rio Zona: coffee beverage with strongly accentuated aroma and taste, strongly resembling iodoform or phenic acid and repugnant flavor [18].

To determine the percentage of defect, a subsample of $100 \mathrm{~g}$ had the defects picked up manually and weighed. The percentages were given dividing the mass of each defect by the initial mass. Sieve retention also used $100 \mathrm{~g}$ subsample and, similarly, the percentage was given by dividing the retained mass by the original mass. Samples were passed through sieves 13 (5.15 $\mathrm{mm}$ mesh) and 17 (6.75 $\mathrm{mm}$ mesh).

2.4. Statistical Analyses. The data expressed in percentage was transformed using the function $y=\arcsin (\sqrt{ } x / 100)$. The 
percentage of defects, sieve retention, plant height, canopy diameter, plagiotropic branch length, and yield were submitted to ANOVA test, and when they were significantly distinct the means were compared with the Tukey test at $P \leq 0.05$. The remaining data was analyzed descriptively.

\section{Results and Discussion}

Coffee trees' plant height, canopy diameter, and plagiotropic branch length did not differ between the treatments (Table 3). Such a fact, probably, is due to low variation in light intensity among the systems. Ricci et al. [4] related that in systems with low soil cover and little variation in shadows' levels, such as coffee trees shaded with Erythrina, which cover only 2 to $6 \%$ of the soil, external morphological changes are not observed in coffee trees. Pezzopane et al. [19] evaluating coffee trees shaded with banana trees also did not find differences in plants' heights on points among the systems, closer or farther from shade trees.

However, the same authors found differences in canopy diameters of coffee trees closer to the banana trees. Ricci et al. [20] observed increases in plant height and canopy diameter of coffee trees in shaded systems when compared with fullsun ones. The greater plant height and canopy diameter represent the coffee tree's effort to compensate for the less light availability under shade, as an attempt to reach solar energy [21].

The treatment closest to shade trees (D1L) promoted faster maturation of cherries and the treatment farther from shade trees (D6E) was the latest to ripen (Figure 2). This result differs from the one mentioned by Ricci et al. [22] that reported later maturation in Obatã coffee in agroforest systems with Erythrina and banana trees. But this result is similar to the one found by Lunz et al. [9] that showed later and nonuniform maturation when solar exposition of coffee cherries of Obatã was greater due to distancing of coffee trees from shade trees.

Regardless of that, maturation speed is reduced by shadow [10], being an important factor for cup quality increase. This is a result, mostly, of reduction of average temperature, as is the case in high "mountain" coffee, which presents a better cup quality [10]. So, it is possible that maturation ends early not because it was sped up, but due to early flowering. According to DaMatta et al. [23], the flower bud remains dormant until the, so-called, "blossom showers" when flowers finish their growth and blossom. Therefore, in a point close to shade trees, soil moisture may have been conserved as shown by Dhanya et al. [24], and the accumulation of smaller rainfall may have been enough to stimulate blossom at these points. This is corroborated by Lunz et al. [9] that identified latter blossoming in more distant coffee plants of shade trees.

Another hypothesis for the early maturation could be competition for water among coffee trees and shade trees due to shared soil volume by roots of both species in D1L, such as the case observed by Coelho et al. [25]. According to Morais et al. [26], hydric stress associated with high temperature can quicken cherries maturation. However, Morinigo [27], working in the same site, period, and plots, did not find any difference in soil moisture in 0,0-20 and 0,20-0,40 m depths.
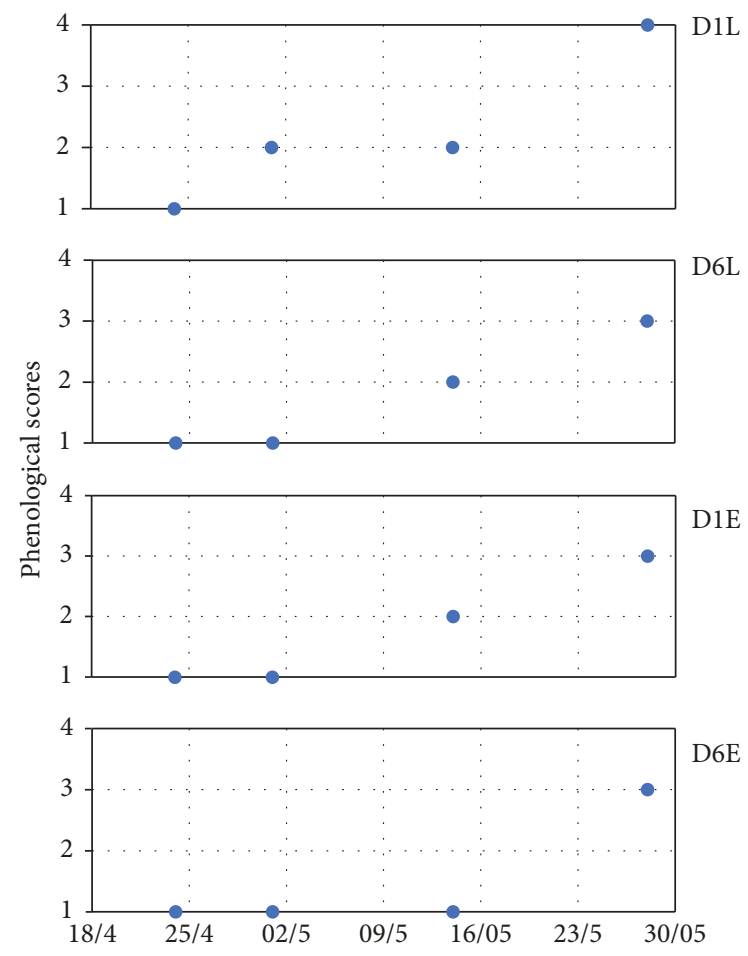

FIGURE 2: Coffee fruits' phenological stages evolution of shaded coffee plants due to shade trees' spatial distribution. Santo Antônio do Jardim, SP, 2015. Phenological scores: (1) green, (2) yellowish green, (3) cherry, and (4) overripe. D1L: coffee trees on shade trees planting rows, distant one meter from the trunk; D6L: coffee trees on shade trees planting rows, distant six meters from the trunk; D1E: coffee plants between the rows of shade trees, parallel to treatment D1L; D6E: coffee plants between the rows of shade trees, parallel to treatment D6L.

Treatments also did not affect Brix degree of ripe cherries. In the closest treatment to shade trees, D1L, the mean was $19.8^{\circ} \mathrm{Bx}$, the intermediate points D6L and D1E showed $21.1^{\circ} \mathrm{Bx}$ and $19.2^{\circ} \mathrm{Bx}$, respectively, and in $\mathrm{D} 6 \mathrm{~L}$, the furthest point from shade trees was $18.3^{\circ} \mathrm{Bx}$. Similar values were found by Silva et al. [28]. However, those authors consider Brix degree as a poor tool to predict cup quality.

The total yields of cherries and of unripe, ripe, and overripe cherries in mass and volume were not affected by shade trees' spatial distribution (Table 4). There was not any difference in the treatment of green coffee beans in total or in any of the maturation stages of cherries (Table 5).

Those results contradict the ones found by Raij et al. [16] that identified loss of yield in coffee trees near shading banana trees. Yield in this work was greater than the Brazilian average, of 22.49 sacks ha $^{-1}$ [29]. It is worthwhile to highlight that, in highly technified systems of shaded coffee, researches in Brazil showed high yields, such as 141 sacks ha $^{-1}$ in coffee plants shaded by Swietenia macrophylla in the Federal District. On the other hand, in native forest coffee yields were a little over 4 sacks ha ${ }^{-1}$ in Minas Gerais [30].

No differences among the treatments were found regarding the percentages of defects (Table 6). Unripe harvested cherries presented a greater percentage of unripe bean defect, 
TABLE 3: Plant height $(\mathrm{m})$, canopy diameter $(\mathrm{m})$, and plagiotropic branch length $(\mathrm{cm})$ of coffee trees due to shade trees spatial distribution. Santo Antônio do Jardim, SP, 2015.

\begin{tabular}{lccc}
\hline Treatments & Plant height & m & $\begin{array}{c}\text { Canopy diameter } \\
\text { Branch length } \\
\text { D1L }\end{array}$ \\
D6L & $1.49^{\text {ns }}$ & $1.45^{\text {ns }}$ & $19.56^{\text {ns }}$ \\
D1E & 1.46 & 1.43 & 17.12 \\
D6E & 1.70 & 1.50 & 19.36 \\
\hline VC\% & 1.57 & 1.41 & 18.11 \\
\hline
\end{tabular}

ns: nonsignificant according to $F$ test at $5 \%$ of significance. D1L: coffee trees on shade trees planting rows, distant one meter from the trunk; D6L: coffee trees on shade trees planting rows, distant six meters from the trunk; D1E: coffee plants between the rows of shade trees, parallel to treatment D1L; D6E: coffee plants between the rows of shade trees, parallel to treatment D6L. VC (\%): variation coefficient.

TABLE 4: Total coffee fruits production after harvesting and production of unripe fruits (UF), ripe fruits (RF), and overripe fruits (OF) after washing and fruit separation due to shade trees spatial distribution. Santo Antônio do Jardim, SP, 2015.

\begin{tabular}{|c|c|c|c|c|}
\hline & UF & RF & $\mathrm{OF}$ & Total (UF + RF + OF) \\
\hline \multicolumn{5}{|c|}{ Coffee fruits } \\
\hline & \multicolumn{4}{|c|}{$\mathrm{kg} \cdot$ plant $^{-1}$} \\
\hline D1L & $0.489^{\text {ns }}$ & $1.262^{\text {ns }}$ & $1.009^{\text {ns }}$ & $2.760^{\mathrm{ns}}$ \\
\hline D6L & 0.676 & 1.267 & 1.072 & 3.015 \\
\hline D1E & 0.744 & 1.260 & 0.680 & 2.684 \\
\hline D6E & 0.845 & 1.680 & 0.866 & 3.391 \\
\hline $\mathrm{VC} \%$ & 46.07 & 37.04 & 38.79 & 34.18 \\
\hline \multicolumn{5}{|c|}{ Volume per plant } \\
\hline & \multicolumn{4}{|c|}{ L.plant ${ }^{-1}$} \\
\hline D1L & $0,850^{\text {ns }}$ & $1,983^{\text {ns }}$ & $1,900^{\text {ns }}$ & $4,733^{\text {ns }}$ \\
\hline D6L & 1,178 & 2,044 & 1,967 & 5,189 \\
\hline D1E & 1,244 & 2,039 & 1,183 & 4,467 \\
\hline D6E & 1,400 & 2,811 & 1,356 & 5,567 \\
\hline $\mathrm{VC} \%$ & 41,80 & 35,95 & 47,96 & 35,42 \\
\hline
\end{tabular}

ns: nonsignificant according to $F$ test at 5\% of significance. D1L: coffee trees on shade trees planting rows, distant one meter from the trunk; D6L: coffee trees on shade trees planting rows, distant six meters from the trunk; D1E: coffee plants between the rows of shade trees, parallel to treatment D1L; D6E: coffee plants between the rows of shade trees, parallel to treatment D6L. VC (\%): variation coefficient.

which was expected. However, that defect was recurrent in all cherries stages of maturation, which is the same as the results found by Carvalho et al. [31]. Black beans were also found in all treatments; still they were more significant in unripe harvested cherries. The fermentation that causes these defects is greater in unripe cherries, once they have higher water content [32].

All treatments presented low percentages, close to zero, of insect damaged beans, $0.3 \%$ for D1L, $0.0 \%$ for D6L, $1.0 \%$ for D1E, and 0.3 for D6E (Table 6). According to Beer et al. [5], trees may be the habitat to natural enemies that control the borer. Besides, the same authors report experiences where the entomopathogenic fungi Beauveria bassiana, which were inoculated in the research site, had better persistence due to shade trees.

The variable bean size, represented by the sieve retention, also had no effect on the treatments due to shade trees' spatial distribution (Table 7). There is consensus in the literature that coffee beans enlarge due to shade [9-12, 22, 33]. Still,
Muschler [11] observed that, in pollarded systems with Erythrina as a shade tree, coffee beans were greater than in systems with heavier shadows. The author then hypothesizes that closer to the shade tree coffee beans were bigger enough to bring the mean up and benefit the system as a whole. However, the same effect was not observed in this work.

Unripe harvested cherries showed a greater percent of small beans (Table 7). This can be explained by the immaturity of cherries. The endosperm is filled until approximately the 17th week after blossoming [23], and during the cherries separation by maturation, all immature fruits are considered unripe, even the ones that have not finished endosperm filling.

Besides, defective beans are smaller than those of high quality [34]. So, beans coming from unripe cherries, the ones that showed the most defects, should be smaller.

To ripe cherries, the worst cup quality was found in D6E, as hard, while the remaining treatments presented beverage softish to D6L and soft to D1L and D1E (Table 8). This result 
TABle 5: Green coffee production due to shade trees spatial distribution. Santo Antônio do Jardim, SP, 2015.

\begin{tabular}{|c|c|c|c|c|}
\hline & UF & $\mathrm{RF}$ & $\mathrm{OF}$ & Total (UF + RF + OF) \\
\hline & \multicolumn{4}{|c|}{$\mathrm{kg} \cdot$ plant $^{-1}$} \\
\hline D1L & $0.084^{\mathrm{ns}}$ & $0.232^{\mathrm{ns}}$ & $0.358^{\mathrm{ns}}$ & $0.674^{\mathrm{ns}}$ \\
\hline D6L & 0.122 & 0.217 & 0.355 & 0.694 \\
\hline $\mathrm{D} 1 \mathrm{E}$ & 0.125 & 0.228 & 0.236 & 0.589 \\
\hline D6E & 0.150 & 0.288 & 0.253 & 0.691 \\
\hline \multirow[t]{2}{*}{$\mathrm{VC} \%$} & 43.61 & 44.67 & 37.97 & 33.53 \\
\hline & \multicolumn{4}{|c|}{ sacks $\cdot \mathrm{ha}^{-1}$} \\
\hline D1L & $5.00^{\mathrm{ns}}$ & $13.79^{\text {ns }}$ & $21.30^{\text {ns }}$ & $40.10^{\text {ns }}$ \\
\hline D6L & 7.28 & 12.91 & 21.10 & 41.30 \\
\hline D1E & 7.42 & 13.54 & 14.02 & 35.00 \\
\hline D6E & 8.94 & 17.16 & 14.45 & 40.60 \\
\hline \multirow[t]{2}{*}{$\mathrm{VC} \%$} & 43.68 & 44.68 & 37.89 & 33.50 \\
\hline & \multicolumn{4}{|c|}{$\mathrm{kg} \cdot \mathrm{ha}^{-1}$} \\
\hline D1L & $299.96^{\mathrm{ns}}$ & $827.28^{\text {ns }}$ & $1277.82^{\mathrm{ns}}$ & $2405.07^{\mathrm{ns}}$ \\
\hline D6L & 436.85 & 774.74 & 1265.92 & 2477.68 \\
\hline $\mathrm{D} 1 \mathrm{E}$ & 445.18 & 812.40 & 840.97 & 2098.56 \\
\hline D6E & 536.25 & 1029.64 & 867.16 & 2433.04 \\
\hline $\mathrm{VC} \%$ & 43.68 & 44.68 & 37.89 & 33.50 \\
\hline
\end{tabular}

ns: nonsignificant according to $F$ test at 5\% of significance. D1L: coffee trees on shade trees planting rows, distant one meter from the trunk; D6L: coffee trees on shade trees planting rows, distant six meters from the trunk; D1E: coffee plants between the rows of shade trees, parallel to treatment D1L; D6E: coffee plants between the rows of shade trees, parallel to treatment D6L. VC (\%): variation coefficient.

TABLE 6: Percentage of black, unripe, and insect damaged beans in samples of unripe fruits (UF), ripe fruits (RF), and overripe fruits (OF) of shaded coffee trees due to shade trees spatial distribution. Santo Antônio do Jardim, SP, 2015.

\begin{tabular}{|c|c|c|c|c|c|c|c|c|c|}
\hline & \multicolumn{3}{|c|}{ Black beans } & \multicolumn{3}{|c|}{ Unripe beans } & \multicolumn{3}{|c|}{ Insect damaged beans } \\
\hline & UF & $\mathrm{RF}$ & OF & UF & $\mathrm{RF}$ & OF & UF & $\mathrm{RF}$ & $\mathrm{OF}$ \\
\hline & & & & & $\%$ & & & & \\
\hline D1L & $14^{\mathrm{ns}}$ & $0^{\mathrm{ns}}$ & $0^{\mathrm{ns}}$ & $29^{\mathrm{ns}}$ & $4^{\mathrm{ns}}$ & $4^{\mathrm{ns}}$ & $0^{\mathrm{ns}}$ & $0^{\mathrm{ns}}$ & $1^{\mathrm{ns}}$ \\
\hline D6L & 17 & 1 & 0 & 22 & 5 & 3 & 0 & 0 & 0 \\
\hline D1E & 15 & 1 & 1 & 35 & 5 & 5 & 0 & 0 & 3 \\
\hline D6E & 14 & 0 & 1 & 26 & 5 & 4 & 1 & 0 & 0 \\
\hline $\mathrm{VC}(\%)$ & 14.9 & 23.7 & 25.3 & 7.8 & 30.0 & 33.4 & 13.9 & 0.0 & 34.3 \\
\hline
\end{tabular}

ns: nonsignificant according to $F$ test at 5\% of significance. D1L: coffee trees on shade trees planting rows, distant one meter from the trunk; D6L: coffee trees on shade trees planting rows, distant six meters from the trunk; D1E: coffee plants between the rows of shade trees, parallel to treatment D1L; D6E: coffee plants between the rows of shade trees, parallel to treatment D6L. VC (\%): variation coefficient.

TABle 7: Percentage of coffee beans of size smaller than sieve 13 and greater than sieve 17 of shaded coffee trees' unripe, ripe, and overripe fruits due to shade trees spatial distributions. Santo Antônio do Jardim, SP, 2015.

\begin{tabular}{lcccccc}
\hline & & Beans $<13$ & & \multicolumn{2}{c}{ Beans $>17$} \\
& UF & RF & OF & UF & RF \\
\hline D1L & $45^{\text {ns }}$ & $11^{\text {ns }}$ & $14^{\text {ns }}$ & $15^{\text {ns }}$ & $19^{\text {ns }}$ \\
D6L & 52 & 16 & 12 & 11 & 18 & $25^{\text {ns }}$ \\
D1E & 53 & 16 & 17 & 11 & 25 \\
D6E & 42 & 14 & 13 & 33.4 & 9 & 21 \\
\hline VC (\%) & 3.8 & 26.4 & 15.0 & 19 & 30.9 \\
\hline
\end{tabular}

ns: nonsignificant according to $F$ test at 5\% of significance. D1L: coffee trees on shade trees planting rows, distant one meter from the trunk; D6L: coffee trees on shade trees planting rows, distant six meters from the trunk; D1E: coffee plants between the rows of shade trees, parallel to treatment D1L; D6E: coffee plants between the rows of shade trees, parallel to treatment D6L. VC (\%): variation coefficient. 
TABLE 8: Beverage scores of samples from unripe fruits (UF), ripe fruits (RF), and overripe (OR) fruits of shaded coffee trees due to shade trees spatial distribution. Santo Antônio do Jardim, SP, 2015.

\begin{tabular}{lccc}
\hline & & Cup quality & \\
& UF & RF & OF \\
\hline D1L & Just soft & Soft & Hard \\
D6L & Hard & Just soft & Soft \\
D1E & Hard & Soft & Soft \\
D6E & Hard & Hard & Soft \\
\hline
\end{tabular}

D1L: coffee trees on shade trees planting rows, distant one meter from the trunk; D6L: coffee trees on shade trees planting rows, distant six meters from the trunk; D1E: coffee plants between the rows of shade trees, parallel to treatment D1L; D6E: coffee plants between the rows of shade trees, parallel to treatment D6L.

was expected once cup quality is well correlated with shadows [10]. Also, in a more distant point from shade trees, microclimate may be similar to full-sun systems [13].

Among overripe cherries, the worst quality was found in $\mathrm{D} 1 \mathrm{~L}$, as hard, and the remaining treatments presented beverage as soft. Once again, this was expected, since maturation was over first in these treatments (Figure 2). Those cherries were, probably, exposed to more adverse weather, since they stayed longer after maturation. Increasing the exposure to opportunist microbes and possibility of fermentation while the cherries are still attached to the coffee tree affects quality [35]. Iamanaka et al. [36] found that cherries that are overripe and still attached to the coffee plant presented the worst beverage quality and greater infestation of pathogenic fungi.

But when the cherries were overripe and do not stay long exposed to weather, they did not differ from those harvested on plane maturation [37]. This explains the best quality of overripe cherries on D6L and D1E. According to Silva et al. [28], the harvested unripe cherries present the worst cup quality, as found in this work, as they are just as soft to D1L and hard to the remaining treatments.

\section{Conclusion}

Shade trees' spatial distribution affects the phenological evolution of cherries and cup quality of coffee trees. Maturation was accelerated in coffee plants closer to shade trees, probably due to anticipated blossom. We recommend monitoring since the blossoming phase to elucidate the results presented here. Also, the best cup quality was obtained in coffee beans coming from coffee trees closer to shade trees, except for overripe cherries.

\section{Conflicts of Interest}

The authors declare that they have no conflicts of interest regarding the publication of this paper.

\section{Acknowledgments}

The authors profusely thank Mr. Jefferson Adorno, the owner of Retiro Santo Antônio farm, his family, and staff for the opportunity to learn with their innovative experience at Kaynã Coffee and for all the essential collaborations to the execution of this work.

\section{References}

[1] C. G. Z. Teixeira and T. S. Milagres, "Economicidade e certificação da cafeicultura familiar na Zona da Mata de Minas Gerais," Pesquisa Agropecuária Tropical, vol. 39, no. 4, pp. 317-329, 2009.

[2] S. P. Pereira, G. F Bartholo, and P. T. G. Guimarães, "Cafés especiais: iniciativas brasileiras e tendências de consumo," Série Documentos, vol. 41, 2004.

[3] P. Läderach, T. Oberthür, S. Cook et al., "Systematic agronomic farm management for improved coffee quality," Field Crops Research, vol. 120, no. 3, pp. 321-329, 2011.

[4] M. S. F. Ricci, D. G. Cocheto Junior, and F. F. D. Almeida, "Condições microclimáticas, fenologia e morfologia externa de cafeeiros em sistemas arborizados e a pleno sol," Coffee Science, vol. 8, no. 3, pp. 379-388, 2013.

[5] J. Beer, R. Muschler, D. Kass, and E. Somarriba, "Shade management in coffee and cacao plantations," Agroforestry Systems, vol. 38, no. 1-3, pp. 139-164, 1998.

[6] F. M. DaMatta, "Ecophysiological constraints on the production of shaded and unshaded coffee: A review," Field Crops Research, vol. 86, no. 2-3, pp. 99-114, 2004.

[7] A. P. Alvarenga, R. S. Vale, L. Couto, F. A. F. Vale, and A. B. Vale, "Aspectos fisiológicos da cultura do café e seu potencial produtivo em sistemas agroflorestais," Agrossilvicultura, vol. 1, no. 2, pp. 195-202, 2004.

[8] M. M. Campanha, R. H. Santos, G. B. Freitas, H. E. Martinez, C. Jaramillo-Botero, and S. L. Garcia, "Análise comparativa das características da serrapilheira e do solo em cafezais (Coffea arabica L.) cultivados em sistema agroflorestal e em monocultura, na Zona da Mata MG," Revista Árvore, vol. 31, no. 5, pp. 805-812, 2007.

[9] A. M. P. Lunz, M. S. Bernardes, C. A. Righi, J. D. Costa, J. L. Favarin, and J. G. Cortez, "Qualidade do café arábica em sistema agroflorestal de seringueira (Hevea brasiliensis Müell. Arg.) e em monocultivo in," in IV Simpósio de Pesquisa dos Cafés do Brasil, Anais... Londrina, Embrapa Café, 2005.

[10] P. Vaast, B. Bertrand, J.-J. Perriot, B. Guyot, and M. Génard, "Fruit thinning and shade improve bean characteristics and beverage quality of coffee (Coffea arabica L.) under optimal conditions," Journal of the Science of Food and Agriculture, vol. 86, no. 2, pp. 197-204, 2006.

[11] R. G. Muschler, "Shade improves coffee quality in a sub-optimal coffee-zone of Costa Rica," Agroforestry Systems, vol. 51, no. 2, pp. 131-139, 2001.

[12] A. S. Bosselmann, K. Dons, T. Oberthur, C. S. Olsen, A. Raebild, and H. Usma, "The influence of shade trees on coffee quality 
in small holder coffee agroforestry systems in Southern Colombia," Agriculture, Ecosystems \& Environment, vol. 129, no. 1-3, pp. 253-260, 2009.

[13] J. R. M. Pezzopane, M. M. S. Marsetti, W. R. Ferrari, and J. E. M. Pezzopane, "Microclimatic alterations in a conilon coffee crop grown shaded by green dwarf coconut trees," Revista Ciência Agronômica, vol. 42, no. 4, pp. 865-871, 2011.

[14] W. K and W. Köppen, Climatologia: con un estudio de los climas de tierra, Mexico: Fondo de cultura económica, Fondo de cultura económica, Mexico, 1 edition, 1948.

[15] N. d. Guimarães, A. d. Gallo, A. Fontanetti et al., "Biomassa e atividade microbiana do solo em diferentes sistemas de cultivo do cafeeiro," Revista de Ciências Agrárias, vol. 40, no. 1, pp. 3444, 2017.

[16] B. van Raij, H. Cantarella, J. A. Quaggio, and A. M. C. Furlani, "Recomendação de Adubação e Calagem para o Estado de São Paulo, Instituto Agronômico - Fundação IAC", in Recomendação de Adubação e Calagem para o Estado de São Paulo, p. 285, Instituto Agronômico - Fundação IAC, Campinas, 1996.

[17] J. R. Pezzopane, M. J. Pedro Júnior, R. A. Thomaziello, and M. B. Camargo, "Escala para avaliação de estádios fenológicos do cafeeiro arábica," Bragantia, vol. 62, no. 3, pp. 499-505, 2003.

[18] Brazil. Ministério da Agricultura, Pecuária e Abastecimento. Intrução Normativa n. 8, de 11 de junho de 2003. Diário oficial da União, poder Executivo, Brasília, 13 jun. 2003.

[19] J. R. Pezzopane, M. J. Pedro Júnior, P. B. Gallo, M. B. Carmargo, and L. C. Fazuoli, "Avaliações fenológicas e agronômicas em café arábica cultivado a pleno sol e consorciado com banana 'Prata Anã', Bragantia, vol. 66, no. 4, pp. 701-709, 2007.

[20] E. Vivier, D. H. Raulet, A. Moretta et al., "Innate or adaptive immunity? The example of natural killer cells," Science, vol. 331, no. 6013, pp. 44-49, 2011.

[21] J. I. Fahl, M. L. C. Carelli, J. Vega, and A. C. Magalhaes, "Nitrogen and irradiance levels affecting net photosynthesis and growth of young coffee plants (Coffea arabica L.)," Journal of Horticultural Science, vol. 69, no. 1, pp. 161-169, 1994.

[22] M. d. Ricci, J. R. Costa, A. N. Pinto, and V. L. Santos, "Cultivo orgânico de cultivares de café a pleno sol e sombreado," Pesquisa Agropecuária Brasileira, vol. 41, no. 4, pp. 569-575, 2006.

[23] F. M. DaMatta, C. P. Ronchi, M. Maestri, and R. S. Barros, "Ecophysiology of coffee growth and production," Brazilian Journal of Plant Physiology, vol. 19, no. 4, pp. 485-510, 2007.

[24] B. Dhanya, B. N. Sathish, S. Viswanath, and S. Purushothaman, "Ecosystem services of native trees: Experiences from two traditional agroforestry systems in Karnataka, Southern India," International Journal of Biodiversity Science, Ecosystem Services \& Management, vol. 10, no. 2, pp. 101-111, 2014.

[25] R. A. Coelho, S. N. Matsumoto, C. L. Lemos, and F. A. Souza, "Nível de sombreamento, umidade do solo e morfologia do cafeeiro em sistemas agroflorestais," Revista Ceres, vol. 57, no. 1, pp. 95-102, 2010.

[26] H. Morais, P. H. Caramori, M. S. Koguishi, J. C. Gomes, and A. M. Ribeiro, "Sombreamento de cafeeiros durante o desenvolvimento das gemas florais e seus efeitos sobre a frutificação e produção," Ciência Rural, vol. 39, no. 2, pp. 400-406, 2009.

[27] K. P. Morinigo, N. D. Guimarães, R. Stolf et al., "Efeitos da distribuição de árvores sobre atributos do solo em cafeeiro sombreado," Coffee Science, vol. 12, no. 4, p. 517, 2017.

[28] S. D. A. Silva, D. M. de Queiroz, F. D. A. C. Pinto, and N. T. Santos, "Coffee quality and its relationship with Brix degree and colorimetric information of coffee cherries," Precision Agriculture, vol. 15, no. 5, pp. 543-554, 2014.
[29] Quarto Levantamento, vol. 2015, 2016, http://www.conab.gov .br/OlalaCMS/uploads/arquivos/15_12_17_09_02_47_boletim_ cafe_d440.

[30] C. Jaramillo-Botero, H. E. P. Martinez, and R. H. S. SANTOS, "Características do café (Coffea arabica L.) sombreado no norte da América Latina e no Brasil: análise comparativa," Coffee Science, vol. 1, no. 2, pp. 94-102, 2006.

[31] A. Carvalho, R. S. Garrutti, A. A. Teixeira, L. M. Pupo, and L. C. Monaco, "Ocorrência dos principais defeitos do café em várias fases de maturação dos frutos," Bragantia, vol. 29, no. unico, pp. 207-220, 1970.

[32] A. A. Custódio, N. M. Gomes, and L. A. Lima, "Efeito da irrigação sobre a classificação do café," Engenharia Agrícola, vol. 27, no. 3, pp. 391-701, 2007.

[33] A. J. J. Souza, S. N. Matsumoto, M. R. Malta, and R. J. Guimarães, "Qualidade do café arborizado e a pleno sol, em manejo póscolheita no sudoeste da Bahia," Coffee Science, vol. 8, no. 2, pp. 109-120, 2013.

[34] J. C. F. Mendonça, A. S. Franca, and L. S. Oliveira, "Physical characterization of non-defective and defective Arabica and Robusta coffees before and after roasting," Journal of Food Engineering, vol. 92, no. 4, pp. 474-479, 2009.

[35] G. S. Giomo, "Uma boa pós-colheita é segredo da qualidade," A Lavoura, vol. 115, no. 688, pp. 12-21, 2012.

[36] B. T. Iamanaka, A. A. Teixeira, A. R. R. Teixeira, M. V. Copetti, N. Bragagnolo, and M. H. Taniwaki, "Reprint of "The mycobiota of coffee beans and its influence on the coffee beverage"," Food Research International, vol. 61, pp. 33-38, 2014.

[37] R. d. Garruti and A. G. Gomes, "Influência do estado de maturação sôbre a qualidade da bebida do café na região do vale do paraíba," Bragantia, vol. 20, no. unico, pp. 989-995, 1961. 


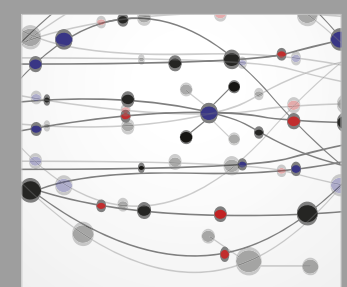

The Scientific World Journal
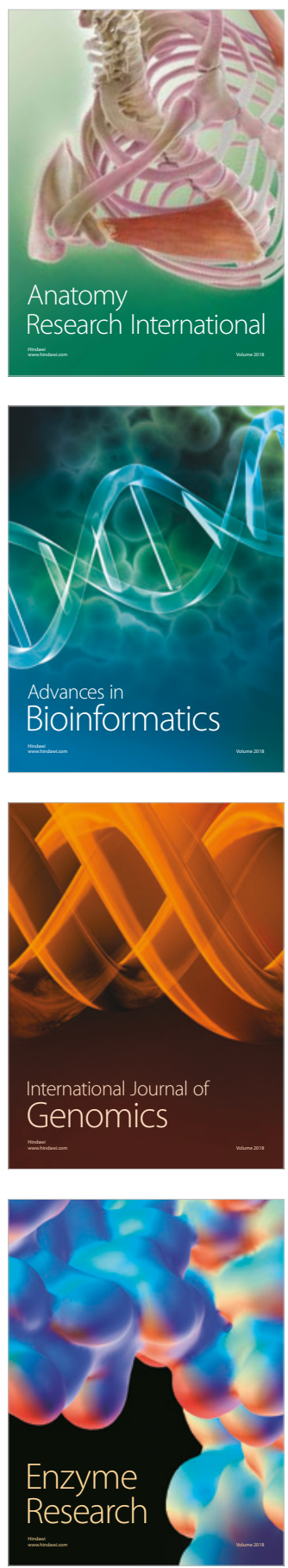
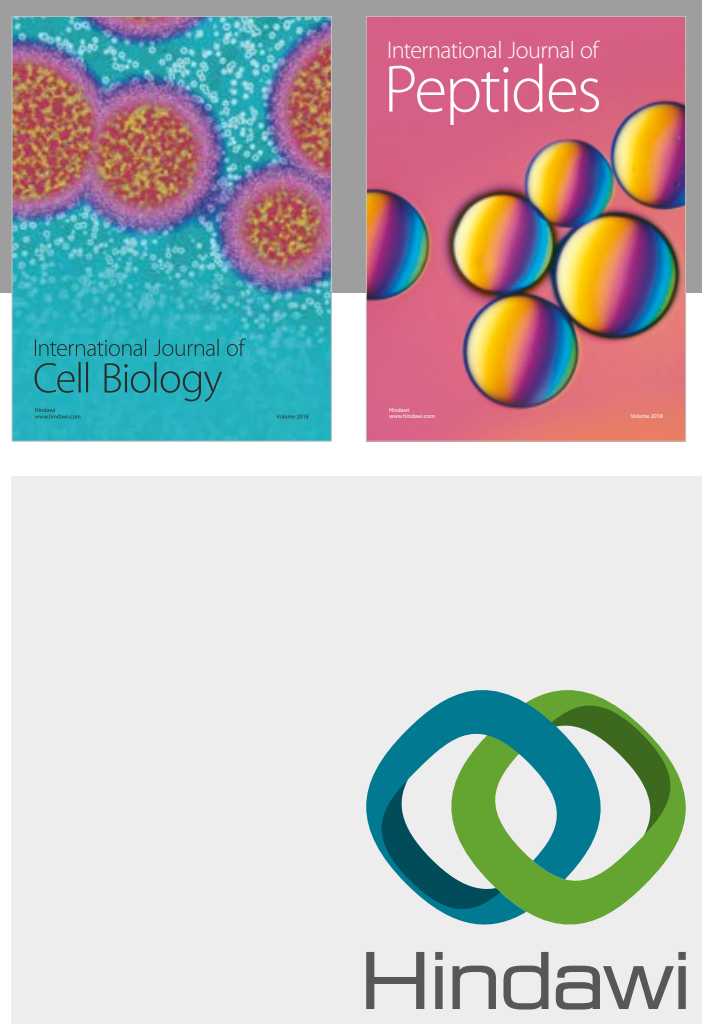

Submit your manuscripts at

www.hindawi.com
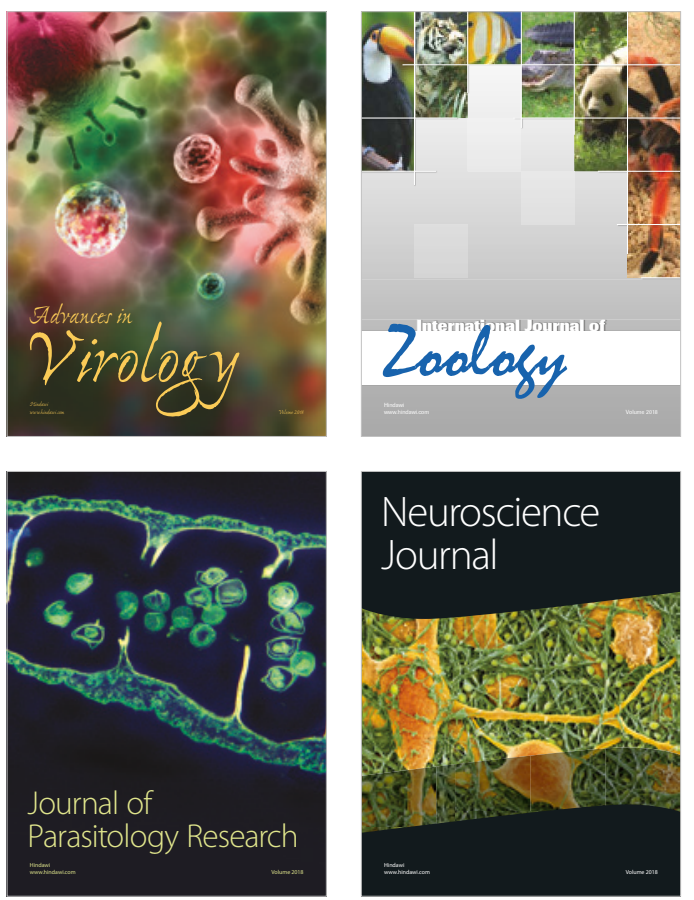
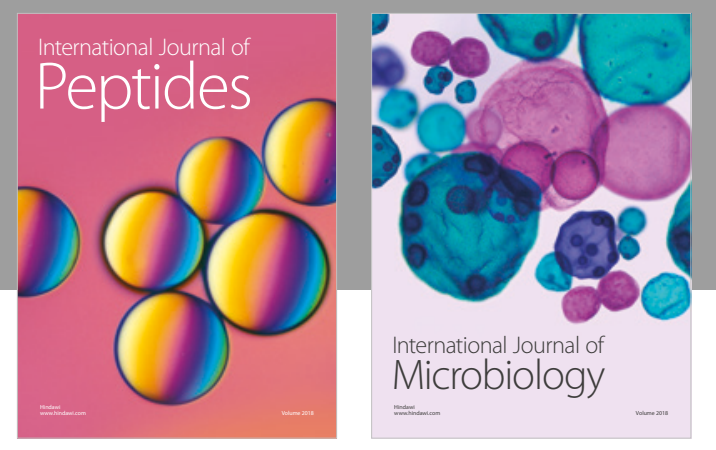

nternational Journal of Microbiology
Journal of
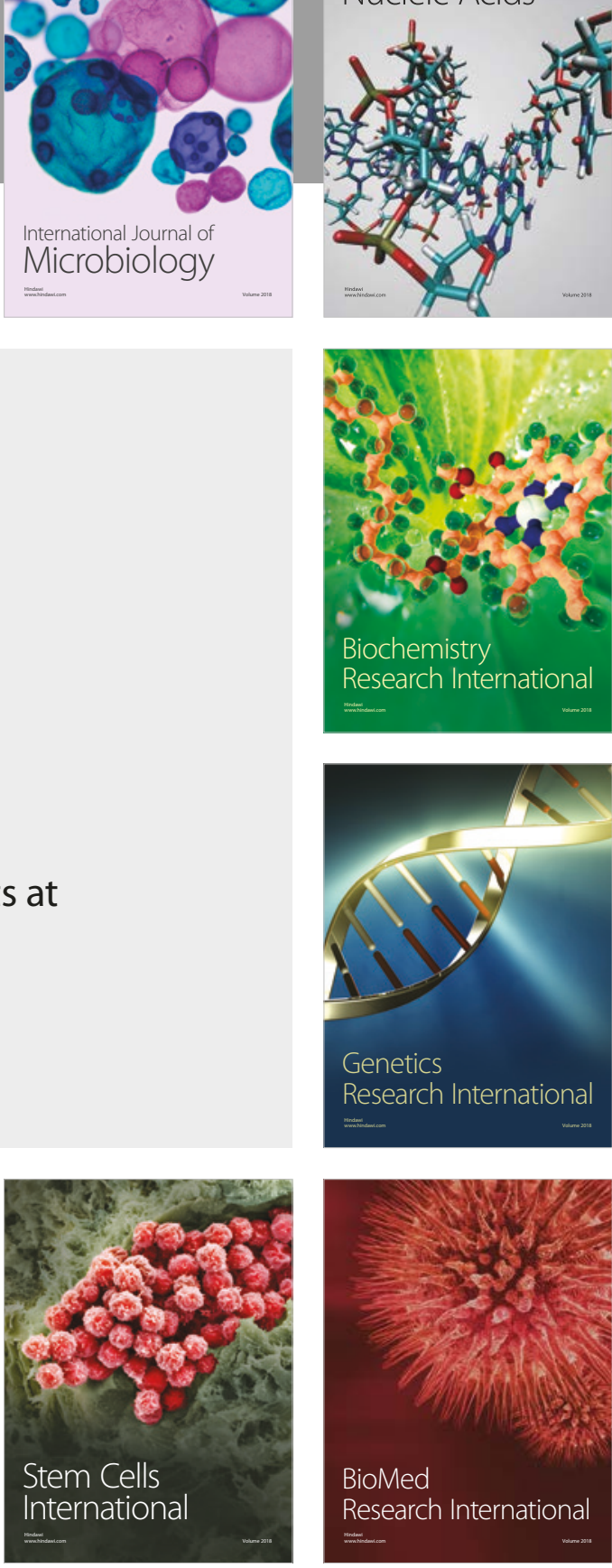
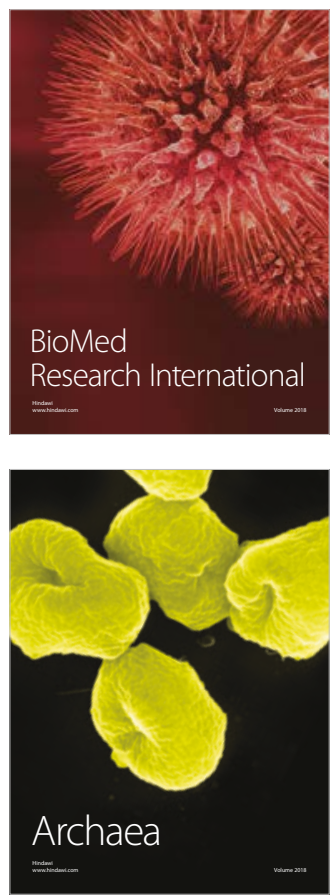